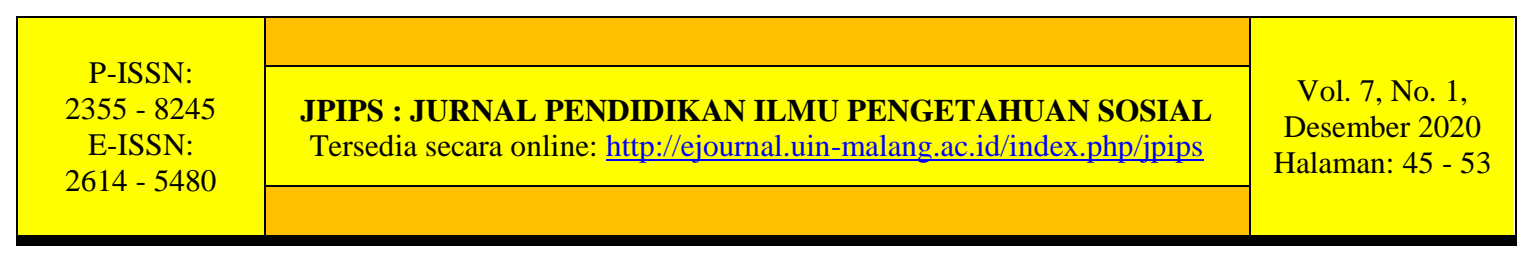

\title{
BEING MUSLIM IN CHINA: HUI ETHNIC PERSPECTIVE
}

\author{
Rois Imron Rosi \\ Universitas Islam Negeri Maulana Malik Ibrahim Malang \\ roisimron@uin-malang.ac.id
}

Diterima: 10-10-2020.; Direvisi: 14-12-2020; Disetujui: 16-12-2020

Permalink/DOI: 10 1886/inins v7i1 10480

Abstrak: Memahami identitas akan membantu individu memahami posisinya di masyarakat. Hal ini juga diharapkan agar mampu membantu setiap individu agar memiliki sikap toleran terhadap perbedaan identitas orang-orang di sekitanya. Lebih lanjut, etnis Hui adalah etnis Muslim mayoritas yang hidup di China Bersama beberapa etnis muslim lainnya seperti Uighur, Dong Xiang, Tajike, Uzbek, dan lainnya. Etnis-etnis Muslim tersebut merupakan etnis minoritas yang hidup Bersama etnis mayoritas bernama 'Han'. Penelitian ini berusaha mengeksplorasi perspektif dan pengalaman etnis Hui dalam mengekspresikan diri sebagai seorang Muslim saat hidup menjadi etnis minoritas di China. Penelitian ini didesain secara kualitatif. Data disajikan dalam bentuk deskripsi. Objek penelitian kali ini adalah 3 orang perempuan dan 1 orang lakilaki China beretnis Hui yang saat ini sedang tinggal dan menempuh studi di Indonesia. Hasil penelitian ini menunjukkan bahwa Muslim di China layaknya Muslim di negara lain yang percaya dengan keesaan tuhan dan melaksanakan ritual-ritual keagamaan, namun terdapat beberapa perbedaan dalam mengekspresikan ritual keagamaan dibandingkan beberapa negara lain. Dalam hal interaksi sosial, Muslim China tidak menutup diri dan juga memposisikan diri secara eksklusif. Mereka terbuka untuk melakukan interaksi dengan mayoritas penduduk China yang notabene non-Muslim. Mereka juga mengkonstruksi dan mengembangkan dua identitas yakni Muslim dan China (Chinese-Muslim) demi menjamin hidup damai dalam harmoni bersama seluruh penduduk China lainnya. Penelitian ini memberikan sumbangsih dalam memperkaya analisis sosiologis mengenai identitas etnis minoritas yang ada di China.

\section{Kata Kunci: Identitas Muslim; Muslim-China; Etnis Hui}

Abstract: Understanding identity helps individual to understand himself/herself and knows his/her position in the society. It is also expected to lead individual having a better tolerant attitude toward other cultures. Furthermore, 'Hui' is a Muslim majority ethnic live in China while Muslim as minority group of the country. This study tries to explore Hui ethnic perspective and experience on being Muslim in China. This study is designed qualitatively. The data is presented in the form of description and explanations. The primary research objects are 3 female and 1 male Hui ethnic who are currently living and studying in Indonesia. The result stated that Muslim in China as represented in many Muslim world who are believing in God and practicing rituals, even there are some different practices experienced by Chinese-Muslim. In term of interaction, Chinese-Muslim are more open with other non-Muslim ethnic, and they develop and construct dual identity in order to live in harmony within 'Han' majority ethnic group. This study will enrich the sociological analysis of identity within minority group.

\section{Keywords: Muslim Identity; Chinese-Muslim; Hui Ethnic}




\section{INTRODUCTION}

The study of minority ethnic is always interesting. Many researchers have different objectives and focuses in studying that cases. Researcher at least found more than 30 articles on studying minority. Some of the articles are focusing on different scope of interpretation and different research sites. The research sites are including Australia, Uganda, India, China, Thailand, United State, United Kingdom, Austria and another Western European Countries. The topics are also vary such as leadership meaning (Sohrabi, 2016), identity development (Spiegler, 2019), minority education (Akhtar \& Narula, 2010; Mcandrew \& Ipgrave, 2010; Schulz, 2013), socio-economic integration (Sezgin, 2019), Muslimah literacy (Islam \& Siddiqui, 2020), meaning of employment (Tariq \& Syed, 2017), minority family (Budhwani et al., 2018), and minority humour (Michael, 2013).

The findings of above researches are also interesting. One research stated that the influence of government and media in Australia in shaping the meaning of leadership among Australian Muslim Leaders. Even though Muslims are minority ethnic, Australian government supports and accommodates them in playing a role in society (Sohrabi, 2016). These findings are being good news for issues of minority in other countries. Another finding stated that dual identity is developed by Muslim minority in order to live with harmony within majority ethnic society (Spiegler, 2019). The research also finds group of Muslims who develop a single identity, but that kind of identity is caused a social problem like the lack of intergroup contact and having problem behaviour in school. Dealing with the finding, the research finally suggests the minority to have dual identity in order to live peacefully within majority ethnic society.

In other side, the concern of minority education is conducted by many researchers. The research on minority Muslim in Uganda suggest the government in Uganda to be more concern in giving an opportunity for Muslim minority in accessing their education as a right of citizen, while the Muslim parent to be more active in supporting the children on accessing education (Schulz, 2013). Another researcher compared the educational condition of minority in England, France, Ontario, Britain, and India. The important of educating pupils live in harmony within differences have been applied and studied in those countries of research while the student or teacher experience in seeing Islam are also varied (Mcandrew \& Ipgrave, 2010). More focused with the role of Islamic schools, research on minority in India see an important role of Madrasah as an informal educational institution for Muslim in West Bengal, India to be the most effective educational institution that give a chance for Muslim India getting better formal education nationally. This Madrasah has been giving opportunity for Muslim getting formal education after graduating from Madrasah. These researches again proved that the issue of minority still being an important and an interesting topic to be discussed (Akhtar \& Narula, 2010).

Another topic such us minority gender inequality is being another topic of discussion. First research found inequality in literacy among Female Muslim and Non-Muslim society in West Bengal, India. The research suggests the policy makers of India being more focus on the human resources development for the betterment of India in the future (Islam \& Siddiqui, 2020). The second research focused on female Muslim meaning of employment, it's because Tariq \& Syed assume that Female-Muslims in United Kingdom are prefer to stay at home rather than working in the office. The research stated that Female-Muslim having a proper strategy in dealing with the field of working and they are very ready to be a leader in that field by their capability and educational degree (Tariq \& Syed, 2017). The third research is about female conception and experience on contraception. The result said that both Muslim and Non-Muslim female are concerning their health especially dealing with health of reproduction (Budhwani et 
al., 2018).

From above researches, the study of minority has been conducting from variety of ways and scopes. From the individual section up to family live. More importantly, some researcher also focusing on minority ethnic history and continued by present condition. A research explored historical context of Muslim minority in Austria was done by one researcher. The research coming from the assumption that European society facing a paradox in both giving religious liberties and restricting the right of Muslim in Europe. The research tries to explore the history of Islam in Austria in order to give a deep understanding of Islam and Muslim as well as reducing Islamophobia. The fact that Muslim in Austria still having different right with other citizen and also, they treat differently in all aspect including economy, law, politic, and so on. So that, the conclusion of the research stated that equality is still long way to go and still being the homework of policy makers in the country (Sezgin, 2019). Besides, the confusing identity is also experienced by Muslim in Austria. The problem of identity is actually experienced by other Muslim minorities in other countries such as Thailand, British, Australia, and western European countries. Muslim in Thailand are being confused in defining themselves as being Thai, Malay or Muslim. Some Thai-Muslim are connecting Thai as being Buddhist, while other never think so. This confusing identity influenced their way of being Muslim in Thailand (Rosi, 2017; Silapacharanan \& Mongkolpradit, 2014). While Muslim in Thailand having confusion in determining their identities, Muslim in Australia is constructing dual identity; being Muslim as well as being Australian or Briton (Basit, 2009; Zulfikar, 2016). It means that constructing dual identity is the way out of problem faced by minority Muslim society. It's in line with the condition in western Europe while most of Muslim are constructing dual identity (Spiegler, 2019).

By the case, it is important to see the construction of identity experienced by other Muslim living in non-Muslim society like China. Because, identity always undergoes transformation (Anbreen, 2015; Çerkezi et al., 2013; Hjörne \& Säljö, 2013; Ifrim, 2013; Li, 2008), therefore it's important to see the identity transformation of Muslim in China. In other side, identity is also formed by daily activities (Hjörne \& Säljö, 2013; Novakova \& Foltinova, 2014), the activities done in different area can be the factor contributing the identity construction. Sometimes, identity is also formed in the educational field (Altugan, 2015; Anbreen, 2015; Arzu \& Issa, 2014; Villodre, 2014). So that, the educational institution where a person study will influence their construction of identity. This research will explore in detail the experienced of being Muslim in China from Hui Ethnic perspectives as a majority Muslim ethnic in that country. This research will enrich the data of how Muslim in China express their Muslim identity in their daily live.

The selection of Chinese Muslim is due to Chinese-Muslim is a minority ethnic lived within majority. Al-Jazeera reported that Muslim population in China is around 1,7\% from all populations. Han is a majority ethnic in china, while the majority Muslim ethnic is Hui and Uighur. Hui and Uighur are living in a land with Han (Lee, 2015). The most populated Muslim in China are located in some provinces like Xinjiang, Ningxia, Henan, and Yunan. While Shandong province having no more than $1 \%$ population of Muslim (Jones-leaning \& Pratt, 2012). In this research, the subjects are coming from the province of Yunan, Henan, and Shandong. It will be interesting because they live in different province and different daily activities. Later, it will be found the different identity that formed by their different activities, school characteristic, parent regulation of being Muslim and so on.

\section{METHODS}


This is a qualitative research in which trying to explore Hui ethnic perspective and experience on being Muslim in China. This research explores 3 female and 1 male Hui ethnic who are currently living and studying in Indonesia. Ma Ling is a key informant of the research because he is really mastering Bahasa Indonesia and having a broad understanding of Islamic history in China. She is an English department student in one of the Islamic University in Indonesia. The researcher asks the informants about their experiences on being Muslim in their daily activities in china.

To analyze the result of interview and observation, researcher will use a main theory of cultural identity which explains two main concept of identity those are identity as being and identity as becoming (Hall, Stuart \& Du Gay, 1996; Hall, 1990). Identity as being correlated with 'who we really are', or can be defined as the identity that influenced by social environment where the individual firstly live in. It based on the history, time, place and individual culture happen in the past, whereas the identity as becoming is correlated with 'what we might become' (Hall, Stuart \& Du Gay, 1996). The result of the interview and observation can be seen by this theory. In other hand, there are some factors contributing the construction of identity those are; (a) identity is affected by the close relationship, (b) identity changes overtime, (c) identity is closely intertwined with power and privilege, (d) identity may evoke emotion, and (e) identity can be negotiated through communication (Jameson, 2007). Dealing with Muslim Identity, scholars have agreed that Muslim identity cannot be determined just by seeing on religious text, but it's also socially, culturally and historically constructed (Kabir, 2010). Socially, for example, Islam experienced differently in Kazakhstan and Saudi Arabia (Hassan, 2008). So that, by using the above theory, we will see how Chinese-Muslim (Hui Ethnic) express their identity as being Muslim in China dealing with the identity guided by religious text and also guided and socially constructed by environment where they live in.

\section{RESULT AND DISCUSSION \\ Result}

\section{Believing in God, Islamic Rituals \& Madzhab}

All the informant noted that the first requirement to be a Muslim is believing the oneness of God or also called tauhid. The oneness of God and the declaration that Muhammad is the prophet are also being the first declaration to be a Muslim. So that, they agree of believing in God as the most important aspect of Muslim identity. It's as stated by informants:

"of course, I do believe in god. We cannot be a Muslim if I am not believing in God, brother. Also believing and declaring Muhammad is the prophet" (Ma Ja Hui)

The quotes stated that to be a Muslim, it's needed a fully declaration of believing in God and his messenger, Muhammad. But, as stated in religious text, being a Muslim is does not enough by just believing in god without practicing the rituals of Islam (praying). But, according to them, being a Muslim is just simply believing in God and no eating pork. It's as said by informants:

"Most of Muslim in China believe -as I observed- that being Muslim is just believing in God and no eating pork. That's all. If you have a time, you can do your praying, if you have no time, you do not need to. But still, like me with my family believe that praying is one of our obligation to be a Muslim" (Jin Yu Jia) 
"being Hui means Muslim, but Muslim here means believing in God and no pork or alcohol. Praying at least in Jumu'ah prayer. They also cannot recite the qur'an. Before I was in boarding school, it is my understanding, but after entering the boarding, my mind is changing. Most of Muslim is not entering the boarding, you can imagine." (Ma Ling)

Besides, the Thariqah is also existed in China. The informant stated:

"the Madzhab are mostly Hanafi. The women also going to Jumu'ah as well as a man, the Thariqah is also exist like Naqsabandi Thariqah. It's having some different with Syafi'i followers like in Indonesia" (Ma Ling)

This statement proved that Muslim in China are mostly practicing Hanafi Madzhab in all aspect religion. While, the existence of thariqah is also seen by the informant.

Wearing Islamic Clothing -Hijab (Headscarf), Gamis, etc-

All the informants agreed that Hijab/Headscarf is one marker of being Muslim. And it's the marker that can distinguished between Muslim and non-Muslim. But, it's not fully practiced in the context of China. Because, they find the most important thing than the headscarf, which is money. Some informant stated:

"yes, Headscarf in important to be Muslim. But, it's not in China. I prefer to cut off my headscarf if I got a job. Job or money is more important to me rather than just a headscarf" (Ma Ling)

"in fact, if I going to go shopping in Mall, I cut off my headscarf, because I'm afraid they -another Chinese- notice my religion, because some of person in my region doesn't like Muslim. But, if I'm going to Henan, I always wear my headscarf." (Jin Yu Jia)

From the statement, we do conclude that being Muslim in China express differently by different citizen in some provinces and based on several conditions. Another informant stated:

"headscarf is important. It's the differentiation of being Muslim. I will keep on my headscarf. No offer. Anything that brings me open my headscarf will be denied by me, even its money or everything. It's Islamic teaching, and my parent told me every day. I was using my headscarf since my early childhood." (Mei Meng Huan)

By the above statements, wearing Islamic clothing in the context of Hui Muslims practiced differently.

\section{Interaction with non-Muslim}

The result of interview found an interesting statement dealing with identity identification. A real Muslim is who are able to accept and interact with non-Muslim individual. Furthermore, real Muslim is who are engage with broader community including non-Muslim community. One of informant stated:

"we are living in China. There are Muslim and non-Muslim. They are all 
Chinese. We need an interaction with them in our daily" (Ma Ja Hui)

"I sometimes open my Headscarf till non-Muslim feel free to interact with me. But, if non-Muslim feel enjoy with me, I am not open mine. Sometimes I do so in maintaining my religion. Islam teach the differences and how to interact with other human being" (Jin Yu Jia)

In the context of China and Hui Muslim which are being informants of the research, there is no border between Muslim and non-Muslim community in term of communication.

\section{Being Muslim or Being Chinese}

Some minority ethnics have confusion of determining the identity as discussed earlier. It's become one of important aspect of this research. While Muslim in Thailand having confusion of determining their identity as Malay or Thai, and other Muslim in Australia, United Kingdom, and western Europe construct dual identity, Chinese Muslims are also experiencing the same. Chinese Muslims are constructing and developing dual identity. They cannot choose either being Muslim or being Chinese, they choose both being Chinese-Muslim.

"I am a Muslim, and I am a Chinese. I am a Chinese Muslim. I cannot identify myself as being just Muslim, or being just Chinese. I am both Chinese, and I am Muslim.” (Ma Ja Hui)

"I am Chinese because I live in China, and I am Muslim because I am believing in God. I am both" (Jin Yu Jia)

"if you ask me to choose, I prefer to be just Muslim. But because I live in China, so I am also Chinese. Shortly, I am Muslim and Chinese" (Mei Meng Huan)

"I am Chinese-Muslim, no discussion. But ethnically, I am and all my friends here are Hui, just see my ID. We have many Muslim ethnics in China" (Ma Ling)

By the statement, there is no confusing in determining the identity among ChineseMuslim. Furthermore, Ma Ling write down the ethnic names exist in China as follow in both Chinese and English language: 回 (Hui), 维吾尔 (Uighur), 东乡 (Dong xiang), 保安 (Baoan), 撒拉 (Sala)，塔吉克 (Tajike)，哈萨克族 (Kazakh)，柯尔克孜族 (Kirghiz)，乌兹别克族 (Uzbek), 塔塔尔族 (Tartar).

\section{Discussion \\ Believing in God, Islamic Rituals \& Madzhab}

The statement stated by the informants that Being a Muslim in their social context is just believing in God and no consuming pork or alcoholic drinking is confirming the statement of some researchers. This statement is confirming the statement which stated that Muslim identity in different region is determined by social context, not just religious text, and it's also constructed by daily activities (Hjörne \& Säljö, 2013; Kabir, 2010; Novakova \& Foltinova, 2014). Because, no one in society giving an advice of how to be Muslim in accordance with religious text. Except, who are in boarding school that given complete advices and teaching on 
being Muslim as stated by religious text. Another important exploration of identity is madzhab (teaching reference). Chinese Muslim are mostly Hanafi madzhab.

\section{Wearing Islamic Clothing -Hijab (Headscarf), Gamis, etc-}

The quote of the informants on waring Islamic Clothing and Headscarf confirmed that identity formed by the environment where she/he lives in. its also strengthen the result of earlier discussion that argued identity can be strongly constructed by educational field, in both school or family (Altugan, 2015; Anbreen, 2015; Arzu \& Issa, 2014; Villodre, 2014). In this case, family playing a very important role, because children are having more time to interact with parent rather than interact with teacher in school. the above statement is one of an important finding of this research.

Dealing with one informant that has different view on wearing headscarf also confirm the statement of earlier discussion which declare that identity is changing overtime and always undergoes transformation depend on condition and situation (Anbreen, 2015; Çerkezi et al., 2013; Hjörne \& Säljö, 2013; Ifrim, 2013; Li, 2008). It's also strengthened the theory of Hall's cultural identity on Identity as being that can be defined as the identity that influenced by social environment where the individual firstly live in. and also can change based on the present condition or said as identity as becoming (Hall, Stuart \& Du Gay, 1996).

More interestingly, one informant who stated the important of headscarf and denying on every proposal that ask her opening the headscarf is also interesting is in line with statement who claimed that Islam always experienced differently in different country (Hassan, 2008).

\section{Interaction with non-Muslim}

The statements of the informants on interaction with non-Muslim actually manifested the teaching of Rasulullah (PbuH) while living in Madina as a new city when the prophet interacted or even integrated with the citizens of Madina (Al-Mubarakfury, 2006). The Prophet teachs us to feel free on interacting with other human being especially non-Muslim person. Even sometimes, interacting with non-Muslim community may be difficult (Qardawi, 2008) as experienced by Jin Yu Jia's quotes. Its difficult because sometimes she forced herself to open her headscarf. It seems easy for Jin Yu Jia, but will be very difficult for a Muslim like Mei Meng Huan who are given strict meaning of Headscarf.

\section{Being Muslim or Being Chinese}

The Muslim ethnic in China are 回 (Hui), 维吾尔 (Uighur), 东乡 (Dong xiang), 保安 (Baoan), 撒拉 (Sala), 塔吉克 (Tajike), 哈萨克族 (Kazakh), 柯尔克孜族 (Kirghiz), 乌兹别克 族 (Uzbek), 塔塔尔族 (Tartar) (Ho, 2010). the Hui ethnic experiences minorly by the informant. The three informants never mention and consider themselves as being Hui, because they feel Chinese identity mean Hui or Muslim. These quotes confirmed and strengthen the statement which stated that to live in harmony, the minority ethnic need to construct and develop the dual identity (Basit, 2009; Spiegler, 2019; Zulfikar, 2016). In fact, there is no conflict between Hui Muslim and non-Muslim in Chine is a real proof that living with harmony between Muslim and Non-Muslim has been achieved. This dual identity also confirmed the statement form Jamerson (2007) who stated that identity can be negotiated through communication. Lastly, all of this result of research strengthens the Hall's theory identity as being and becoming.

\section{CONCLUSION}

This research explores Hui ethnic perspective and experience on being Muslim in China. Muslim in China is represented is a person who believed in god, and not consuming pork or even 
alcoholic drinking. Many of Muslim are do not practice praying except Jumu'ah, but few of them are practicing rituals as practiced by many Muslim in the world. Most of Muslim in China are Hanafi madzhab, and the informants of the research stated the important of wearing headscarf while some of them see something more important than headscarf which is money. Dealing with interaction with non-Muslim, all Chinese-Muslim agreed that Muslim teaching is forbid the feeling of exclusivity, so that they feel open to interact with non-Muslim in China. The other aspect, the Chinese construct dual identity as being Chinese and Muslim in the same time. It's for living in harmony within majority ethnic society.

\section{REFERENCES}

Akhtar, N., \& Narula, M. (2010). The Role of Indian Madrasahs in Providing Access to Mainstream Education for Muslim Minority Students : A West Bengal Experience. 91-107. https://doi.org/10.1007/s12134-009-0120-1

Al-Mubarakfury, S. (2006). Sirah Nabawiyah. Pustaka Al-Kautsar.

Altugan, A. S. (2015). The Relationship Between Cultural Identity and Learning. Procedia Social and Behavioral Sciences, 186, 1159-1162. https://doi.org/10.1016/j.sbspro.2015.04.161

Anbreen, T. (2015). The Influence of English Second Language Learning on Pakistani University Students' Identity. Procedia - Social and Behavioral Sciences, 192, 379-387. https://doi.org/10.1016/j.sbspro.2015.06.054

Arzu, A., \& Issa, T. (2014). An Effect on Cultural Identity: Dialect. Procedia - Social and Behavioral Sciences, 143, 555-562. https://doi.org/10.1016/j.sbspro.2014.07.435

Basit, T. M. (2009). White British; dual heritage; Brithis Mudlim: Young Britons' conceptualization of identity and citizenship. British Educational Research Journal., 35 (5), 732-742.

Budhwani, H., Anderson, J., \& Hearld, K. R. (2018). Muslim Women 's use of contraception in the United States. 1-8. https://doi.org/10.1186/s12978-017-0439-6

Çerkezi, E., Dumi, A., Çelo, E., \& Pulaj, E. (2013). Intercultural Communication, Innovations and Standardization of Cultural Identity in Teaching Method. Procedia - Social and Behavioral Sciences, 75, 154-162. https://doi.org/10.1016/j.sbspro.2013.04.018

Hall, Stuart \& Du Gay, P. (1996). Questions of cultural identity. Sage Publication.

Hall, S. (1990). Cultural identity and diaspora (J. Rutherford (ed.)). Lawrence \& Wishart.

Hassan, R. (2008). Inside Muslim minds. Melbourne University Press.

Hjörne, E., \& Säljö, R. (2013). Representing diversity in education: Student identities in contexts of learning and instruction. International Journal of Educational Research, 63, 1-4. https://doi.org/10.1016/j.ijer.2012.10.001

Ho, W.-Y. (2010). Journal of Muslim Minority Affairs Islam, China and the Internet: Negotiating Residual Cyberspace between Hegemonic Patriotism and Connectivity to the Ummah Islam, China and the Internet: Negotiating Residual Cyberspace between Hegemonic Patriotism an. 923160374. https://doi.org/10.1080/13602001003650622

Ifrim, N. (2013). Education and Interculturality in Approaching Post-totalitarian Identity Discourse: Interactive Views on Re-reading the Romanian Cultural Identity. Procedia Social and Behavioral Sciences, 93, 18-22. https://doi.org/10.1016/j.sbspro.2013.09.145

Islam, S., \& Siddiqui, L. (2020). A geographical analysis of gender inequality in literacy among Muslims of West Bengal , India ( 2001 - 2011 ). GeoJournal, 85(5), 1325-1354. https://doi.org/10.1007/s10708-019-10025-1 
Jameson, D. A. (2007). Reconceptualizing cultural identity and its role in intercultural business communication. Journal of Business Communication, 44(3), 199-235. https://doi.org/10.1177/0021943607301346

Jones-leaning, M., \& Pratt, D. (2012). Islam in China: From Silk Road to Separatism. The Muslim World, 102(2001), 308-334. https://doi.org/10.1111/j.1478-1913.2012.01399.x

Kabir, N. A. (2010). Young British Muslim: Identity, Culture, Politics and the Media. Edinburgh University Press Ltd.

Lee, R. (2015). Muslims in China and their Relations with the State (Issue August).

$\mathrm{Li}, \mathrm{X}$. (2008). Identity re/construction of cross-cultural graduate students. Proquest Education Journal, 1-267.

Mcandrew, M., \& Ipgrave, J. (2010). The Education of Minority Muslim Students : Comparative Perspective. 1-4. https://doi.org/10.1007/s12134-009-0126-8

Michael, J. (2013). American Muslims stand up and speak out : trajectories of humor in Muslim American stand-up comedy. 129-153. https://doi.org/10.1007/s11562-011-0183-6

Novakova, M., \& Foltinova, E. (2014). The Ordinary - Everyday - Commonplace as a Reference of Cultural Identity. Procedia - Social and Behavioral Sciences, 122, 114-118. https://doi.org/10.1016/j.sbspro.2014.01.1312

Qardawi, Y. (2008). Fiqh of Muslim minorities: Contentious issues and recommended solutions. New Vision.

Rosi, R. I. (2017). Cultural Identity of Thai-Muslim Students in Their Learning Activities at Maulana Malik Ibrahim State Islamic University of Malang, Indonesia (I. Junko (ed.)). Japan Book, Inc.

Schulz, D. E. (2013). What makes a good minority Muslim? Educational policy and the paradoxes of Muslim schooling in Uganda. 53-70. https://doi.org/10.1007/s11562-0130246-y

Sezgin, Z. (2019). Islam and Muslim Minorities in Austria: Historical Context and Current Challenges of Integration. 869-886.

Silapacharanan, S., \& Mongkolpradit, W. (2014). Community Responses to Cultural Identity of the Three Religious Communities: A Case Study in Chachoengsao Province, Thailand. Procedia - Social and Behavioral Sciences, 36(April), 723-731. https://doi.org/10.1016/j.sbspro.2012.03.079

Sohrabi, H. (2016). Identity and Muslim leadership : the case of Australian Muslim leaders. 116. https://doi.org/10.1007/s11562-015-0325-3

Spiegler, O. (2019). Dual Identity Development and Adjustment in Muslim Minority Adolescents. Journal of Youth and Adolescence, 1924-1937. https://doi.org/10.1007/s10964-019-01117-9

Tariq, M., \& Syed, J. (2017). Intersectionality at Work: South Asian Muslim Women's Experiences of Employment and Leadership in the United Kingdom. 510-522. https://doi.org/10.1007/s11199-017-0741-3

Villodre, M. del M. B. (2014). Cultural Identity and Using Music in the Intercultural Educational Process. Procedia - Social and Behavioral Sciences, 132, 235-240. https://doi.org/10.1016/j.sbspro.2014.04.304

Zulfikar, T. (2016). RELIGIOUS IDENTITY OF INDONESIAN-AUSTRALIAN MUSLIM YOUTH : Family, schooling and community (Muslim schoolgirls experience of schooling ). June. 